\title{
Application of Health Belief Model on Factors Affecting Participation in the National Health Insurance Scheme among Informal Sector Workers in Kudus, Central Java
}

\author{
Anom Dwi Prakoso'), Endang Sutisna Sulaeman², Arief Suryono3) \\ 1)Masters Program in Public Health, Universitas Sebelas Maret \\ ${ }^{2)}$ Faculty of Medicine, Universitas Sebelas Maret \\ 3)Faculty of Law, Universitas Sebelas Maret
}

\section{ABSTRACT}

Background: Universal Health Coverage is the mandate of the Pancasila and 1945 Constitution. UHC's target on January $1^{\text {st }}$, 2019 is that all Indonesians are covered by the National Health Insurance (JKN). Meanwhile, the participation of informal workers as of May 1, 2019 only reached $57 \%$. The cross-subsidy system is not optimal and the budget deficit will continue to be experienced because there are still many citizens who have not joined JKN. This study aimed to analyze the determinants of the participation of informal workers in the national health insurance program in Kudus using the Health Belief Model.

Subjects and Method: This was case control study, conducted in 5 sub-districts in Kudus Regency, Central Java from September to October 2019. Total of 200 informal workers were selected by purposive sampling, it was divided into two groups including 100 in case group and a 100 in control group. The dependent variable was the participation of informal workers in the $\mathrm{JKN}$ program. The independent variables were perception of vulnerability, perception of seriousness, perspective of benefits, family support, selfefficacy, and social environment. The data collection was performed using a questionnaire and data analysis with logistic regression using stata 13 .
Results: The participation of informal workers in the JKN program increased with knowledge of $\geq$ Senior high school $(b=5.09 ; 95 \% \mathrm{CI}=0.32$ to 9.87; $\mathrm{p}=0.036$ ), high perception of vulnerability $(b=3.01 ; 95 \% \mathrm{CI}=0.26$ to $5.75 ; \mathrm{p}=0.031)$, high perceived seriousness $(b=5.38 ; 95 \% \mathrm{CI}=2.14$ to 8.61; $\mathrm{p}=0.001)$, high perceived benefit $(\mathrm{b}=3.86$; $95 \% \mathrm{CI}=0.39$ to $7.34 ; \mathrm{p}=0.029$ ), strong family support $(b=7.26 ; 95 \% \mathrm{CI}=2.69$ to $11.82 ; \mathrm{p}=$ 0.002), strong self-efficacy $(b=3.98$; $95 \% \mathrm{CI}=$ 0.98 to $6.98 ; \mathrm{p}=0.009$ ) and a supportive social environment $(b=4.51 ; 95 \% \mathrm{CI}=1.61$ to $7.40 ; \mathrm{p}=$ 0.002).

Conclusion: Knowledge, perception of vulnerability, perception of seriousness, perceived usefulness, family support and social environment influence the participation of informal workers in the JKN program.

Keywords: universal health coverage, national health insurance, health belief model

\section{Correspondence:}

Anom Dwi Prakoso, Masters Program in Public Health, Universitas Sebelas Maret, Jl. Ir. Sutami 36A, Surakarta 57126, Central Java, Indonesia. Email: anomdwiprakoso@gmail.com. Mobile: o895363054393.

\section{Cite this as:}

Prakoso AD, Sulaeman ES, Suryono A (2020). Application of Health Belief Model on Factors Affecting Participation in the National Health Insurance Scheme among Informal Sector Workers in Kudus, Central Java. J Health Policy Manage. 5(1): 61-73. https://doi.org/10.26911/thejhpm.2020.05.01.06 


\section{BACKGROUND}

Universal Health Coverage is the target of Sustainable Development Goals point 3.8 which aims to build a safe and healthy and sustainable world in 2030 that has been approved by 193 countries of the World Health Organization (Hogan et al., 2018). UHC aims to fulfill the right to access to health services to all people and to avoid falling into poverty due to treatment of catastrophic diseases and diseases with operations that are in fact high financial burdens (Boerma et al., 2014).

The 58th World Health Assembly (WHA) in Geneva suggests that each country embodies its commitment to developing UHC. In accordance with the mandate of Pancasila and 1945 Constitution Article 28H paragraph 1 and 3 and Article 34 paragraph 1, 2, 3 to guarantee health and social security for all citizens. The mandate was finally facilitated by the government through the National Health Insurance program (Government of Indonesia, 1945).

In line with the Healthy Indonesia Program the third pillar, JKN, which is mandatory and covers the entire population of Indonesia, a legal entity was formed, namely BPJS in 2013. BPJS is a form of follow-up to the National Social Security System (SJSN). Through this SJSN, all people are expected to get health services whose impact is to improve health status (GoI, 2004).

Based on BPJS Health data on JKN program participants, as of May 1, 2019, national coverage has only reached 221,105,092 people, the population of Indonesia is estimated to reach around 260 million people per 2018 (BPJS Health, 2019).

The number of informal workers in Indonesia is still dominant compared to the formal sector with 73.98 million people or (58.22\%) of the total number of workers engaged in informal activities. Meanwhile, the coverage of JKN membership in informal workers or PBPU as of May 1, 2019 reached 31,877,532 people. From this data, it is known that $57 \%$ of infor- mal workers have not participated in the JKN program (Central Statistics Agency, 2018; BPJS Health, 2019).

Coverage of health insurance membership in Central Java Province is $83.7 \%$ or 34.50 million people are included in the JKN scheme. The informal sector is still the most dominant that has not participated in the JKN scheme or has not registered with the BPJS. It is known that $3,898,745$ or $35.6 \%$ of informal workers have participated in or participated in the JKN program (Central Statistics Agency, 2018; National Social Security Council, 2019).

Based on the results of a preliminary study conducted at the Kudus District Health BPJS office per May, the number of JKN membership was 827,461 people out of a total population of 861,430 people. 33,969 people have not participated in the JKN program. It is known that the number of informal workers who have not participated in the JKN program is 31,127 (Kudus Central Statistics Agency, 2018).

There are still many participants who have not participated in the JKN program and many participants who drop out of payments frustrate the system of cross-subsidies from healthy to sick. This certainly adds to the problems experienced by BPJS Health. One result is that the burden of financial burdens becomes very high at the Health BPJS which ultimately results in a budget deficit (Kusumaningrum and Azinar, 2018; Darma et al., 2018).

\section{SUBJECTS AND METHOD}

\section{Study Design}

This was observational analytic with case control approach. The study was conducted in 5 Subdistricts located in Kudus Regency, Central Java from September to October 2019.

\section{Population dan Sample}

A total 200 informal workers were selected by purposive sampling. It was divided into two groups including 100 informal workers who have not participated in the JKN program as 
case group and 100 informal workers who participated in the JKN program as control group.

\section{Study Variables}

The dependent variable in this study is the participation of informal workers in the JKN program. Meanwhile, the independent variables are knowledge, perception of vulnerability, perception of seriousness, perceived usefulness, family support, and social environment.

\section{Operational Definition of Variables}

Knowledge was everything related to information relating to national health insurance that is known and realized. The measuring instrument used was a questionnaire. The scale of the data was continuous, and for analytical purposes, the data was converted into a dichotomy with code 1 (high) and code o (low).

Vulnerability perception was an individual's positive or negative assessment of the risk for illness and suffering from illness. The measuring instrument used was a questionnaire. The scale of the data was continuous, and for analytical purposes, the data was converted into a dichotomy with code 1 (high) and code o (low).

Perception of seriousness was an individual's subjective perception of how severe the physical and social consequences of the illness are suffered. The measuring instrument used was a questionnaire. The scale of the data was continuous, and for analytical purposes, the data was converted into a dichotomy with code 1 (high) and code o (low).

The perception of benefits was the perception that individuals feel about the benefits and benefits of following the JKN program. The measuring instrument used was a questionnaire. The data scale was continuous, and for analytical purposes, the data was converted into a dichotomy with code 1 (high) and code 0 (low).

Family support was a motivating factor for someone to adopt a new behavior in the behavior that is family support includes attitudes, behaviors that are manifested in actions so that informal workers follow JKN. The measuring instrument used was a questionnaire. The measurement scale was continuous, and for analytical purposes, the data was converted into a dichotomy with code 1 (strong) and code $\mathrm{O}$ (weak).

Self-efficacy was a belief or ability from within a person to follow the $\mathrm{JKN}$ program. The measuring instrument used was a questionnaire. The measurement scale was continuous, and for analytical purposes, the data was converted into a dichotomy with code 1 (strong) and code o (weak).

Social environment was a learning process that is carried out through observing the behavior of other individuals who are considered to have more value, such as many friends or relatives around them who have followed or have not yet followed the JKN program. The measurement scale was continuous, and for analytical purposes, the data was converted into a dichotomy with code 1 (supporting) and code o (not supporting).

\section{Data Analysis}

Univariate analysis explains the general description of data and is carried out on each variable, namely: knowledge, perception of vulnerability, perception of seriousness, perceived usefulness, family support, and social environment are described in $\mathrm{n}$ and\%.

Bivariate analysis was used to determine the effect of each independent variable (knowledge, perception of vulnerability, perception of seriousness, perceived usefulness, family support, and social environment) on the dependent variable (participation of informal workers in the JKN program). Chi-square statistical test and calculation of odds ratio (OR) with a confidence level (confidence interval) is $95 \%$.

Multivariate analysis is used to see the effect of more than one independent variable. The method used in this study is logistic regression analysis using Stata 13. 
Prakoso et al./ Application of Health Belief Model on Factors Affecting Participation

6. Research Ethics

This study was conducted based on research ethics, namely informed consent, anonymity, confidentiality, and ethical eligibility. Ethics permit in this study was obtained from the Health Research Ethics Commission Dr. Moewardi Hospital, Surakarta, Indonesia, No. 1,042 / VIII / HREC / 2019.

Table 1.The characteristics of categorical data samples

\begin{tabular}{|c|c|c|c|}
\hline Variable & & $\mathbf{n}$ & $\%$ \\
\hline Age & $<43$ years & 94 & 47.0 \\
\hline & $\geq 43$ years & 106 & 53.0 \\
\hline Education & Low (<Senior high school) & 122 & 61.0 \\
\hline & High ( $\geq$ Senior high school) & 78 & 39.0 \\
\hline Income & Low & 96 & 48.0 \\
\hline & High & 104 & 52.0 \\
\hline Knowledge & Low & 79 & 39.5 \\
\hline & High & 121 & 60.5 \\
\hline Perceived susceptibility & Low & 69 & 34.5 \\
\hline & High & 131 & 65.5 \\
\hline Perceived Seriousness & Low & 108 & 54.0 \\
\hline & High & 92 & 46.0 \\
\hline Perceived Benefit & Low & 84 & 42.0 \\
\hline & High & 116 & 58.0 \\
\hline Family Support & Weak & 92 & 46.0 \\
\hline & Strong & 108 & 54.0 \\
\hline Self-Efficacy & Weak & 94 & 47.0 \\
\hline & Strong & 106 & 53.0 \\
\hline Social Environment & Weak & 75 & 37.5 \\
\hline & Strong & 125 & 62.5 \\
\hline
\end{tabular}

\section{Univariate analysis}

Table 1 shows that informal workers aged $<43$ years were 94 (47.0\%), while those aged $\geq 43$ years were 106 (53.0\%), informal workers with low education ( $<$ SMA) were 122 (61.0\%), while informal workers with high education are 78 (39.0\%).

Informal workers who have low income $(<\mathrm{Rp} 2,044,467)$ are $96(48.0 \%)$, those who have a high income ( $\geq$ Rp 2,044,467) are 104 (52.0\%), informal workers with low knowledge are $79(39.5 \%)$, while informal workers those with high knowledge are 121 (60.5\%), informal workers with low disease susceptibility perception are $69(34.5 \%)$.

Meanwhile informal workers with high disease susceptibility perception were 131
(65.5\%), informal workers with low disease seriousness perception were 108 (54.0\%), while informal workers with high disease seriousness perception were 92 (46.0\%), informal workers with low perceived benefits is 84 (42.0\%).

Informal workers with high benefit perceptions were 116 (58.0\%), informal workers with weak family support were 92 (46.0\%), while informal workers with strong family support were 108 (54.0\%), informal workers with weak self-efficacy is 94 (47.0\%).

Informal workers with strong self-efficacy were 106 (53.0\%), informal workers with weak social environments were $75(37.5 \%)$, while informal workers with strong social environments were 125 (62.5\%). 
Prakoso et al./ Application of Health Belief Model on Factors Affecting Participation

\section{Bivariate Analysis}

The bivariate analysis explains the effect of each independent variable on the dependent variable (participation of informal workers in the JKN program). The method used is the chisquare test.

Table 2.Bivariate analysis of a number of factors affecting JKN participation

\begin{tabular}{|c|c|c|c|c|c|c|c|c|}
\hline \multirow{3}{*}{ Independent Variable } & \multicolumn{4}{|c|}{ JKN Participation } & \multirow{2}{*}{\multicolumn{2}{|c|}{ Total }} & \multirow{3}{*}{ OR } & \multirow{3}{*}{$\mathbf{p}$} \\
\hline & \multicolumn{2}{|c|}{ Before } & \multicolumn{2}{|c|}{ After } & & & & \\
\hline & $\mathbf{N}$ & $\%$ & $\mathbf{N}$ & $\%$ & $\mathbf{N}$ & $\%$ & & \\
\hline \multicolumn{9}{|l|}{ Knowledge } \\
\hline Low & 64 & 81.0 & 15 & 19.0 & 79 & 100 & 10.07 & $<0.001$ \\
\hline High & 36 & 29.8 & 85 & 70.2 & 121 & 100 & & \\
\hline \multicolumn{9}{|l|}{ Perceived Susceptibility } \\
\hline Low & 43 & 62.3 & 26 & 37.7 & 69 & 100 & 2.14 & 0.011 \\
\hline High & 57 & 43.5 & 74 & 56.5 & 131 & 100 & & \\
\hline \multicolumn{9}{|l|}{ Perceived Seriousness } \\
\hline Low & 93 & 86.1 & 15 & 13.9 & 108 & 100 & 75.28 & $<0.001$ \\
\hline High & 7 & 7.6 & 85 & 92.4 & 92 & 100 & & \\
\hline \multicolumn{9}{|l|}{ Perceived Benefit } \\
\hline Low & 59 & 59.6 & 40 & 40.4 & 99 & 100 & $49 \cdot 50$ & 0.007 \\
\hline High & 41 & 40.6 & 60 & 59.4 & 101 & 100 & & \\
\hline \multicolumn{9}{|l|}{ Family Support } \\
\hline Weak & 86 & 93.5 & 6 & 6.5 & 92 & 100 & 96,28 & $<0.001$ \\
\hline Strong & 14 & 13.0 & 94 & 87.0 & 108 & 100 & & \\
\hline \multicolumn{9}{|l|}{ Self-Efficacy } \\
\hline Weak & 74 & 78.7 & 20 & 21.3 & 94 & 100 & 11.38 & $<0.001$ \\
\hline Strong & 26 & 24.4 & 80 & $75 \cdot 5$ & 106 & 100 & & \\
\hline \multicolumn{9}{|l|}{ Social Environment } \\
\hline Not supporting & 72 & 96.0 & 3 & 4.0 & 75 & 100 & 83.14 & $<0.001$ \\
\hline Supporting & 28 & 22.4 & 97 & 77.6 & 125 & 100 & & \\
\hline
\end{tabular}

Table 2 shows that informal workers with high knowledge increased $\mathrm{JKN}$ participation $(\mathrm{OR}=$ 10.07; $\mathrm{p}<0.001)$. Informal workers with high vulnerability perceptions increased $\mathrm{JKN}$ participation ( $\mathrm{OR}=2.14 ; \mathrm{p}=0.011)$. Informal workers with high seriousness perception increased $\mathrm{JKN}$ participation $(\mathrm{OR}=75.28 ; \mathrm{p}<0.001)$.

Informal workers with high perceived benefits increase $J K N$ participation $(\mathrm{OR}=49.50$; $p=$ 0.007). Informal workers with strong family support increased $\mathrm{JKN}$ participation $(\mathrm{OR}=$ 96.28; $\mathrm{p}<0.001)$. Informal workers with strong self-efficacy increased $\mathrm{JKN}$ participation $(\mathrm{OR}=$ 11.38; $\mathrm{p}<0.001$ ).

Informal workers with a strong social environment increased $\mathrm{JKN}$ participation $(\mathrm{OR}=$ 83.14; $\mathrm{p}<0.001$ ).

\section{Multivariate Analysis}

Multivariate analysis is used to see the effect of more than one independent variable. The method used in this study is logistic regression analysis using Stata 13.

Table 3 shows that Knowledge has an influence on JKN partitions. Informal workers with high knowledge have the possibility to participate in the JKN program as many as 5.09 units higher than those with low knowledge $(b=5.09 ; 95 \% \mathrm{CI}=0.32$ to $9.87 ; \mathrm{p}=$ o.036).Perception of vulnerability has an influence on JKN participation. Informal workers with high vulnerability perceptions have the possibility to participate in the JKN program as many as 3.01 units higher than those with low 
vulnerability perceptions $(b=3.01 ; 95 \% \mathrm{CI}=$ 0.26 to $5.75 ; \mathrm{p}=0.031$ ).

Perception of seriousness has an influence on JKN participation. Informal workers with high seriousness perceptions have the possibility to participate in the JKN program as many as 5.38 units higher than those with low seriousness perceptions $(b=5.38 ; 95 \% \mathrm{CI}=$ 2.14 to $8.61 ; \mathrm{p}=0.001$ ).

Perceived benefits have an influence on JKN participation. Informal workers with high perceived benefits were likely to participate in the JKN program, which was 3.86 units higher than those with low perceived benefits $(b=$ 3.86; 95\% CI 0.39 or 7.34; $p=0.029$ ).

Family support has an influence on JKN participation. Informal workers with strong
Family support were likely to participate in the JKN program by 7.26 units higher than those with weak family support $(\mathrm{b}=7.26$; $95 \% \mathrm{CI}=$ 2.69 to $11.82 ; \mathrm{p}=0.002$ ).

Self-efficacy has an influence on JKN participation. Informal workers with strong selfefficacy were 3.98 units more likely to participate in the JKN program than those with weak self-efficacy $(\mathrm{b}=3.98 ; 95 \% \mathrm{CI}=0.98$ to 6.98; $\mathrm{p}=$ 0.009).

The social environment has an influence on JKN participation. Informal workers with a supportive social environment are likely to participate in the $\mathrm{JKN}$ program by 4.51 units higher than those with a weak social environment $(b=4.51 ; 95 \% \mathrm{CI}=1.61$ to $7.40 ; \mathrm{p}=$ 0.002).

Tabel 3. Multiple logistic regression analysis on factors affecting JKN participation

\begin{tabular}{|c|c|c|c|c|}
\hline \multirow[b]{2}{*}{ Independent Variable } & \multirow{2}{*}{$\begin{array}{l}\text { Regression } \\
\text { coefficient } \\
\text { (b) }\end{array}$} & \multicolumn{2}{|c|}{$95 \% \mathrm{CI}$} & \multirow[b]{2}{*}{$\mathbf{p}$} \\
\hline & & $\begin{array}{c}\text { Lower } \\
\text { Limit }\end{array}$ & $\begin{array}{c}\text { Upper } \\
\text { Limit }\end{array}$ & \\
\hline Education (high) & 5.09 & 0.32 & 9.87 & 0.036 \\
\hline Perception of vulnerability (high) & 3.01 & 0.26 & 5.75 & 0.031 \\
\hline Perception of seriousness (high) & $5 \cdot 38$ & 2.14 & 8.61 & 0.001 \\
\hline Perception of benefit (high) & 3.86 & 0.39 & $7 \cdot 34$ & 0.029 \\
\hline Family support (strong) & 7.26 & 2.69 & 11.82 & 0.002 \\
\hline Self-efficacy (strong) & 3.98 & 0.98 & 6.98 & 0.009 \\
\hline Social environment (supporting) & 4.51 & 1.61 & $7 \cdot 40$ & 0.002 \\
\hline $\mathrm{N}$ obervation $=200$ & & & & \\
\hline Log likelihood =-14.65 & & & & \\
\hline Pseudo R2= 89.43\% & & & & \\
\hline $\mathrm{p}<0.001$ & & & & \\
\hline
\end{tabular}

\section{DISCUSSION \\ 1. The effect of knowledge on JKN par- ticipation}

The results of this study indicate that knowledge has an influence on JKN participation. Informal workers who have high knowledge increase the possibility to participate in $\mathrm{JKN}$ programs by 5.09 units higher than informal workers who have low knowledge.

Noubiap et al. (2013) stated that lack of knowledge is one of the factors that influence the awareness of informal workers to take part in health insurance in Cameroon. Only
$25.4 \%$ of the total respondents know and understand the scheme and information about national health insurance in Cameroon. In line with the study of Zhai et al. (2017) that one of the factors influencing variations in perceptions of equality and benefits in national health care programs in China is knowledge. Knowledge of the type of health insurance chosen determines the perception of health justice in the national health care program in China. 
According to Alkhamis (2017) states that foreigners' knowledge about the benefits of health insurance is very limited so that the use of health insurance is not optimal. Knowledge of benefits has been shown to increase the use of health insurance for foreigners in Saudi Arabia.

In accordance with Puspitasari (2017) that knowledge is one of the factors that has a significant influence on JKN membership participation. Workers in the informal sector with highly trained knowledge increase the possibility of participating in the JKN program independently.

According to Obse et al. (2015) states that formal sector employee knowledge in Addis Ababa about the concept and elements of health insurance is relatively low. Some national health insurance concepts such as risk collection and sharing are not well understood. The study participants considered health insurance only as a mechanism for prepayments without risk sharing among scheme members.

\section{The effect of perceived susceptibility on JKN participation}

The results of this study indicate that the perception of vulnerability has an influence on JKN participation. Informal workers who have a high perception of vulnerability to a disease increase the possibility to participate in the JKN program by 3.01 units higher than informal workers who have a low perception of vulnerability.

It $\mathrm{w}$ in line with the results of study by Guntari et al. (2019) showing that there is a significant relationship between perceptions of disease vulnerability and participation of nonwage workers or informal workers. Perception of vulnerability refers to beliefs about the possibility of getting a certain disease or condition. Vulnerability to illness due to unhealthy lifestyles, raises the willingness to participate in the JKN program in order to avoid the risk of large financial losses due to illness suffered.

Setiyaningsih et al. (2016) states that there is an indirect relationship between the per- ception of vulnerability and the behavior of efforts to prevent hypertension through an intermediate variable, namely threat perception. Vulnerability perception refers to subjective assessment of risks to health problems. Individuals who believe that they have a low risk of disease are more likely to take unhealthy actions, and individuals who view their high risk will be more likely to engage in behaviors to reduce their risk of disease.

This is in line with a study conducted by Trisnawan (2015), stating that the perceived susceptibility has a significant relationship to the change in behavior of a student in seeking treatment when experiencing health problems. Students who are vulnerable to an illness will immediately seek treatment when suffering from illness due to fear of getting worse. In line with the HBM theory, if a person is susceptible to his condition, then the possibility to act will be greater.

\section{The effect of perceived seriousness on JKN participation}

The results of this study indicate that the perception of seriousness has an influence on JKN participation. Informal workers who have a high seriousness perception of a disease increase the possibility of 5.38 higher units to participate in the JKN program compared to informal workers who have a low seriousness perception.

This is in line with study by Melinda et al. (2016) which states that there is a relationship between the perception of seriousness and community interest in JKN participation. The more severe illness or health problems owned by respondents affected the high interest of the community in JKN participation. This was evidenced by the statistically significant relationship test $(\mathrm{OR}=7.86$; 95\% CI; 1.6337.90: $\mathrm{p}=$ 0.009). Study subjects with high seriousness perceptions were more likely to be interested in JKN participation by 7.9 times greater than respondents with low seriousness perceptions. 
According to Lattof's (2018), it is known that the health status and illnesses or injuries experienced increase the efforts of workers in the informal sector in Ghana to obtain health insurance and seek health care.

Supporting other studies, Sunaryo et al. (2016) state that the perception of the seriousness of the disease is the variable most associated with adherence to antiretroviral therapy. The heavier the risk of disease, the more likely the individual feels threatened. This threat encourages individual actions to take preventive and cure diseases.

\section{The effect of perceived benefit on JKN participation}

The results of this study indicate that the perception of benefits has an influence on JKN participation. Informal workers who have a perceived benefit of a high JKN program increase the probability of 3.86 units higher to participate in the $\mathrm{JKN}$ program compared to informal workers who have a low benefit perception.

According to study conducted by Widhiastuti et al. (2019), there is a significant relationship between perceived benefits and JKN membership. 89.36\% of JKN participants had a high perception of benefit towards JKN. Respondents who felt the high benefits of JKN increased 4.53 times more likely to participate in the JKN program. Evidenced by the results of statistical tests that show a significant relationship (OR=4.53; 95\% CI = 2.15-9.55).

The low perception of benefits from informal workers in rural areas in Southwest Nigeria is one of the challenges for national health insurance schemes. The participation of informal workers is known to be still low because most of the 345 households surveyed have a poor perception of the benefits of national health insurance (Adewole et al., 2015).

Zhai et al (2017) explains the benefits derived from the health care system affect health justice. About $73 \%$ of respondents who have a high-benefit perception of the health care system feel health justice in China. The benefits derived from the national health program in China are determined by the type of insurance along with the health insurance benefits chosen by that person according to the desires and needs of each individual.

\section{The effect of family support on JKN participation}

The results of this study indicate that family support has an influence on JKN participation. Informal workers who have family support for a strong JKN program increase the likelihood of 7.26 units higher to participate in the JKN program compared to informal workers who have weak family support.

Study from Kusumaningrum and Azinar (2018) shows that family support in the form of information support related to $\mathrm{JKN}$ is the provision of information on fees, how to register, where to register, the benefits of JKN influence someone to join the JKN program. Self-employed with strong family support has been proven to increase $\mathrm{JKN}$ participation by 2 times higher than weak support. It is known from the results of statistical tests that showed a significant relationship $(\mathrm{OR}=2.00$; $95 \% \mathrm{CI}=$ 1.24 to $3.20 ; \mathrm{p}=0.008)$.

Study by Adewole et al. (2017) states that social support from poor families affects the involvement of informal deposit workers in community-based national health insurance in Nigeria. The involvement of informal workers in national health insurance schemes in Nigeria is one of the challenges that becomes homework for governments in Nigeria and other developing countries.

Family support includes social and financial support from spouses, children and sonsin-law proven to influence the participation of the informal sector independently of the JKN program in Poncol Village, East Pekalongan District, Pekalongan City. It is found statistically that there is a significant relationship ( $\mathrm{Pa}-$ ngestika et al., 2017). 


\section{The effect of self-efficacy on JKN par- ticipation}

The results of this study indicate that self-efficacy has an influence on JKN participation. Informal workers who have strong self-efficacy against strong JKN programs increase the likelihood of 3.98 units higher to participate in JKN programs compared to informal workers who have weak self-efficacy.

Study Thornton et al. (2010) show that the personal experience of informal workers and the experiences of others in using health insurance affect people's access to health insurance and group out payment of health insurance premiums in Nicaragua. Self-efficacy is influenced by several factors, namely individual experiences, experiences of other people's success, verbal persuasion and physiological and emotional states.

James et al. (2018) states that statistically shows that there is a significant influence between self-efficacy and utilization of health services. It is known that students who have high self-efficacy are proven to increase 2.48 units higher utilization of health services compared to students with low efficacy.

This is in line with the study of Kan et al. (2015) which shows that self-efficacy has a significant influence on health insurance decision making. Some $89 \%$ of respondents who have high self-efficacy choose to make their own decisions about health insurance.

Self-efficacy is proven to influence changes in a person's behavior to act. High selfefficacy increases by 0.16 times towards low back pain prevention behavior (Sari et al., 2018).

\section{The effect of the social environment on JKN participation}

The results of this study indicate that the social environment has an influence on JKN participation. Informal workers who have a strong social environment against a strong JKN program increase the probability of 4.51 units higher to participate in the JKN program com- pared to informal workers who have a weak social environment.

This is in line with the results of Puspitasari's (2017) which shows that the closest people and peers have an important role to influence someone to follow the JKN program through information about JKN. This study shows that there is a relationship between social support and PBPU's participation in the JKN program.

This is consistent with Odeyemi's study (2014) which states that poor social support in the form of information and support from the government affects the involvement of informal deposit workers in community-based national health insurance in Nigeria.

Oh and Jung, (2017) state that social ties influence the decision of immigrant workers in Korea to buy health insurance. The social ties of immigrant workers in Korea do not provide useful information about benefits, costs, and ways to use health insurance. Social learning and normative influence occur within social networks and this mechanism seems to prevent the purchase of health insurance.

Environmental conditions can provide and maintain certain responses to a person. Most individual behaviors are obtained from learning outcomes through observing the behavior exhibited by other people who are made models (Simpson, 2015).

\section{AUTHOR CONTRIBUTION}

Anom Dwi Prakoso as the lead author play a role in data retrieval and processing research data. Endang Sutisna Sulaeman plays a role in the formulation of the framework of thought, supporting theories and research discussions. Arief Suryono played a role in the substance of the background and research discussion

\section{CONFLICT OF INTEREST}

There is no conflict of interest in this study. 


\section{FUNDING AND SPONSORSHIP}

This study is self-funded.

\section{ACKNOWLEDGEMENT}

We thank all informal workers who were willing to participate and to be the subjects.

\section{REFERENCE}

Adewole DA, Adebayo AM, Udeh EI, Shaahu VN, Dairo MD (2015). Payment for health care and perception of the national health insurance scheme in a rural area in Southwest Nigeria, Am J Trop Med Hyg, 93(3): 648-654. Https://doi.org/10.4269/ajtmh.14-0245.

Adewole DA, Akanbi SA, Osungbade KO, Bello

$S$ (2017). Expanding health insurance scheme in the informal sector in Nigeria: awareness as a potential demand-side tool. Pan Afr Med J, 27(52): 1-11. https://doi.org/10.11604/pamj.2017.27.52.11092.

Alkhamis A (2017). Knowledge of health insurance benefits among male. Saudi Med J, 38(6): 642-653. https://doi.org/10.15537/smj.2017.6.18177.

Central Bureau of Statistics (2018). Keadaan ketenagakerjaan Indonesia februari 2018 (The situation of Indonesian employment in February 2018). Retrieved from http://www.turc.or.id/wp-content/uploads/2018/o6/bps_berita-resmistatsitik_keadaan-ketenagakerjaanindonesia-februari-2018.pdf.

Badan Pusat Statistik Kabupaten Kudus (2018). Kudus dalam angka 2018. Retrieved from https://kuduskab.bps.go.id/publication/2018/o8/16/7812ae46 f6b77cf56e22b1f5/kabupaten-kudusdalam-angka-2018.html.

Boerma T, Eozenou P, Evans D, Evans T, Kieny M, Wagstaff A (2014). Monitoring progress towards universal health coverage at country and global levels, PLoS Med, 11(9): 1-8. https://doi.org/10.1371/jour- nal.pmed.1001731.

Darma S, Juanita, Rochadi, RK (2018). BPJS barrier to strategic purchasing of primary care service at public and private health facilities in Subulussalam, Aceh. J Health Policy Manage, 3(2): 81-91. https://doi.org/doi.org/10.26911/thejhpm.2018.03.02 .03 .

Febriani GA, Rahardjo SS, Murti B (2017). Biopsychosocial determinants of human papilloma virus immunization in women of reproductive age in Surakarta, Central Java. J Health Promot Behav, 3(1): 6777. https://doi.org/10.26911/thejhpb.2018.03.01.07.

Guntari GAS, Hasanbasri M (2019). Hubungan sosiodemografi, sosioekonomi, persepsi kerentanan penyakit, dan kepercayaan (trust) terhadap partisipasi pekerja bukan penerima upah dalam program jaminan kesehatan nasional di Kabupaten Karanganyar, 1-11 (Sociodemographic, socio-economic relations, perception of disease vulnerability, and trust in the participation of non-wage workers in the national health insurance program in Karanganyar Regency, 1-11). Retrieved from http://etd. sitory.ugm.ac.id/downloadfile/157680/potongan/S2-2018-403245-title.pdf.

Hogan DR, Stevens GA, Hosseinpoor AR, Boerma T (2018). Monitoring universal health coverage within the sustainable development goals: development and baseline data for an index of essential health services. Lancet Glob Health, 6(2): e152-e168. https://doi.org/10.1016/S2214-109X(17)30472-2

Indonesian Government. Undang-Undang Dasar Negara Republik Indonesia Tahun 1945. Retrieved from http://jdih.pom.go.id/uud1945.pdf

James TG, Sullivan MK, Dumeny L, Lindsey K, Cheong J, Nicolette G, Dumeny L (2018). Health insurance literacy and health 
service utilization among college students. J Am Coll Health, o(o): 1-7. https://doi.org/10.1080/07448481.2018.1538151

Kan K, Barnes AJ, Hanoch Y, Federman AD (2015). Self-Efficacy in insurance decision making. Am J Manag Care, 21(4): 247-254. Retrieved from https://www.ajmc.com/journals/issue/2015/2015vol21-n4/self-efficacy-in-insurance-decision-making-among-older-adults? $\mathrm{p}=3$

Kusumaningrum A, Azinar M (2018). Kepesertaan masyarakat dalam jaminan kesehatan nasional secara mandiri (Community participation in national health insurance independently). HIGEIA, 2(1); 149-160. Retrieved from http://journal.unnes.ac.id/sju/index.php/higeia\%oakepesertaan

Lattof SR (2018). Health insurance and careseeking behaviours of female migrants in Accra, Ghana. Health Policy Plan, o(o): 1-11. https://doi. org/10.1093/heapol/czyO12

Melinda, Suparwati A, Suryoputro A (2016). Faktor-faktor yang berhubungan dengan minat masyarakat dalam keikutsertaan bpjs mandiri di Kecamatan Bener Kabupaten Purworejo (Factors related to community interest in the participation of independent bpjs in Bener Subdistrict, Purworejo Regency). Jurnal Kesehatan Masyarakat, 4(4): 86-93. Retrieved from https://media.neliti.com/media/publications/108162-id-faktor-faktor-yangberhubungan-dengan-mi.pdf

National Social Security Board (2019). Cakupan kepesertaan jaminan kesehatan nasional (Coverage of national health insurance membership). Retrieved from http://sismonev.djsn.go.id/kepesertaan/

Noubiap JJN, Joko, WYA, Obama JMN, Bigna JJR (2013). Community-based health insurance knowledge, concern, preferences, and financial planning for health care among informal sector workers in a health district of Douala, Cameroon. Pan Afr Med J, 8688(o9): 1-9. https://doi.org/10.11604/pamj.2013.16.17.2279

Obse A, Hailemariam D, Normand C (2015). Knowledge of and preferences for health insurance among formal sector employees in Addis Ababa: a qualitative study. BMC Health Serv Res, 15(318): 1-11. https://doi.org/10.1186/s12913-015-9888

Odeyemi IAO. (2014). Community-based health insurance programmes and the national health insurance scheme of $\mathrm{Ni}$ geria: challenges to uptake and integration. Int J Equity Health, 13(20): 1-13. https://doi.org/10.1186/1475-9276-13-20

Oh H, Jung C (2017). korean immigrants don't buy health insurance: the influences of culture on self- employed korean immigrants focusing on structure and functions of social networks. Soc Sci Med, 10(191): 194-201. https://doi.org/10.1016/j.socscimed. 2017.09.012.

Pangestika VF, Jati SP, Sriatmi A (2017). Faktor-faktor yang berhubungan dengan kepesertaan sektor informal dalam bpjs kesehatan mandiri di Kelurahan Poncol, Kecamatan Pekalongan Timur, Kota Pekalongan (Factors related to the participation of the informal sector in independent health bpjs in Poncol Village, East Pekalongan District, Pekalongan City). Jurnal Kesehatan Masyarakat, 5(3): 39-49. Retrieved from http://ejournal-s1.undip.ac.id/index.php/jkm\%oafaktor

Puspitasari Y (2017). Faktor yang memengaruhi partisipasi kepesertaan jaminan kesehatan nasional pada pekerja bukan penerima upah di Desa Kasiyan Timur wilayah kerja Puskesmas Kasiyan Kabupaten Jember tahun 2016 (Factors affecting the participation of national 
health insurance participation in nonwage workers in the East Kasiyan Village, the working area of the Kasiyan Health Center, Jember Regency in 2016). Retrieved from http://repository.unej.ac.id/bitstream/handle/123456789/80978/yuli\%2opuspitasari\%20-\%20142110101190.pdf? sequence $=1$ Sari SA, Indarto D, Wijaya M (2018). Application of Health Belief Model on Preventive Behaviors of Patients with Low Back Pain. J Health Promot Behav, 3(3): 192198. https://doi.org/10.26911/thejhpb.2018.03.03.06

Setiyaningsih R, Tamtomo D, Suryani N (2016). Health belief model: determinants of hypertension prevention behavior in adults at community health center, Sukoharjo, Central Java, 1(3): 161-171. J Health Promot Behav. https://doi.org/10.26911/thejhpb.2016.01.03.03

Simpson V (2015). Models and theories to support health behavior intervention and program planning. Retrieved from https://extension.purdue.edu/extmedia/hhs/hhs-792-w.pdf

Social Insurance Administration Organization (2019). Data peserta progam JKN (092). Retrieved from https://bpjs-kesehatan.go.id/b39df9ae7a30a5c7d4bdof54d763b447.pdf

Sunaryo, Demartoto A, Adriyani RB (2016). Association between knowledge, perceived seriousness, perceived benefit and barrier, and family support on adherence to anti- retrovirus therapy in patients with HIV/AIDS. J Health Promot Behav, 1(1): 55-62.

Thornton RL, Hatt LE, Field EM, Islam M, Gonza MA (2010). Social security health insurance for the informal sector in Nicaragua: a randomized evaluation, Health Econ, 206(6): 181-206. https://doi.org/10.1002/hec

Trisnawan PD (2015). Determinan perilaku pencarian pengobatan mahasiswa fakultas kedokteran dan ilmu kesehatan UIN Syarif Hidayatullah Jakarta. Retrieved from http://repository.uinjkt. ac.id/dspace/handle/123456789/28897.

Widhiastuti IAP, Januraga PP, Wirawan DN (2019). Hubungan persepsi manfaat dengan kepesertaan jkn secara mandiri di Puskesmas Denpasar Timur (Relationship of perceived benefits with membership of JKN independently at the East Denpasar Health Center). PHPMA, 3(2): 1-8. Retrieved from https://media.neliti.com/media/publications/21511-IDperceived-benefits-as-variable-relatedto-voluntary-enrollment-in-the-nationalh.pdf

Zhai S, Wang P, Dong Q, Ren X, Cai J, Coyte PC (2017). A study on the equality and benefit of China's national health care system. Int J Equity Health, 16(155): 1-11. https://doi.org/10.1186/s12939-017o653-4 